\title{
EXPERIMENTAL STUDIES AT 6 - 12 GPA OF THE ONDERMATJIE HYPABYSSAL KIMBERLITE
}

\author{
Roger H. Mitch ell \\ Department of Geology, Lakehead University Thunder Bay, Canada
}

\section{INTRODUCTION}

Despite many years of investigation the nature of the source rocks of kimberlite magma remains unidentified. In part, this is a consequence of the absence of rapidlyquenched lavas which might represent primary kimberlite magma. Typically kimberlites are hybrid rocks consisting of mantle-derived xenocrysts, cryptogenic macrocrysts and primary minerals. Commonly, their mineralogy and petrography indicat es that their parental magmas have undergone flow differentiation and fractional crystallization. Samples of aphanitic kimberlite which are considered to represent the crystallization products of relatively unmodified magma have been the subjects of high pressure melting experiments in efforts to determin e what rock typesmight represent their source rocks. In other approaches synthetic analogs of simplified bulk composition have been utilised. Other approaches are based purely upon geochemical arguments and arrive at very differ ent con clusions. All of these studies are summarized by Mitchell (1995). Many experimental petrologists approach the problem by identifying liquidus phases at high pressure and assuming these are in equilibrium with source rocks. Another, less common, approach is to determine phase assemblages present over the whole melting interval and iden tify near-solidus assemblages representing potential source in metasomatized or veined mantle (Foley 1992).

This abstract summarise the results of a preliminary investigation of the phase relation ships for a macrocryst- and xenocryst-poor, aphanitic hypabyssal kimberlite from Ondermatjie, Republic of South Africa. The bulk composition of this material is richer in titanium and total iron than the Wesselton aphanitic kimberlite previously studied experimentally at high pressure by Edgar \& Charbonneau (1993). The kimberlite consists of microphenocrysts of forsteritic olivine set in a fine grained groundmass consisting principally of resorbed perovskite, subhedral magnesian ulvospinel - magnetite, serpophitic serpentine and calcite. The whole rock composition (wt.\%) is: 26.06 $\mathrm{SiO}_{2} ; 4.04 \mathrm{TiO}_{2} ; 3.70 \mathrm{Al}_{2} \mathrm{O}_{3} ; 14.38 \mathrm{Fe}_{2} \mathrm{O}_{3} ; 0.18 \mathrm{MnO}$; $20.05 \mathrm{MgO} ; 16.58 \mathrm{CaO} ; 1.46 \mathrm{~K}_{2} \mathrm{O} ; 0.01 \mathrm{Na}_{2} \mathrm{O} ; 0.84$ $\mathrm{P}_{2} \mathrm{O}_{5} ; 0.09 \mathrm{Cr}_{2} \mathrm{O}_{3} ; 11.58$ LOI; 98.97 Total. The Clement conta min ation index of 1.30 indicates that this kimberlite can be considered as free of contamination by crustal rocks.

\section{Experimental Techniques}

All experiments wereundertaken using theMA6/8 2000ton uniaxial split-sphere multianvil apparatus located at the University of Alberta, Edmonton (Walter et al. 1995) at pressures ranging from $6-12 \mathrm{GPa}$ and temperatures from $1000-1300^{\circ} \mathrm{C}$. Starting material consisted of finely powdered kimberlite. Only the volatiles present in the starting composition were used in the experiments and no attempt was made to control oxygen fugacity. All experiments were conducted using either graphite (6 - 7 $\mathrm{GPa})$ or platinum (8 -12 $\mathrm{GPa})$ capsules load in to a furnace assembly consisting of a stepped graphite (6 - 7 $\mathrm{GPa})$ or $\mathrm{LaCrO}_{3}(8-12 \mathrm{GPa})$ heater contained within a semi-sintered $\mathrm{MgO}-\mathrm{Cr}_{2} \mathrm{O}_{3}(5 \%)$ octahedron of either $18 \mathrm{~mm}(6-7 \mathrm{GPa})$ or $14 \mathrm{~mm}(8-12 \mathrm{GPa})$ edge length. Although none of the experiments were reversed the experimental approach of completelymelting the starting material at $1600^{\circ} \mathrm{C}$ and then holding the charges at this temperature $\left(\sim 100-200^{\circ} \mathrm{C}\right.$ above the liquidus temperature) for 1-2 hours, followed by reducing the temperature to the desired experimental value is considered to result in a close approach to equilibrium. All temperatures were monitored with W5Re-W26Re thermocouples. Estimated temperature and pressures uncertainties are $\pm 10^{\circ} \mathrm{C}$ and $\pm 0.5 \mathrm{GPa}$, respectively (Walter et al. 1995).

Experience with this equipment has demonstrated that at the temperatures and pressures prevailing equilibration tends to be rapid and is reach ed within the duration ( 8 hours) of the experiment. 
Experimental charges were quenched to ambient conditions by first reducing temperature and then releasing pressure. Problems encoun tered in interpreting the experiments were: (1) the common occurrence of significant quenching effects on the phase assemblages present as represented by compositional zoning and heterogeneous inter-grain compositions, especially with respect to garnets; (2) phase segregation within the charges, with commonly one end of the capsule dominat ed by quenched carbonate liquid; (3) temperature gradients with the capsule, resulting in preferential crystallization of near-liquidus phases at one end of the capsule. Similar problems were encountered by Edgar \& Charbonneau (1993) using this same apparatus. Regardless of these problems, observed phase assemblages are considered to be adequate for establishing the liquidus and subliquidus phase relationships.

All experimental products were examined by back-scatter ed electron imagery and the phases iden tified by energy dispersive X-ray spectrometry using a Hitachi 570 scanning electron microscope at Lakehead University. The compositi ons of phases were deter mined by quantitative energy dispersive X-ray spectrometry (EDS) using the LINK ISIS analytical system incorporating a Super ATWLightElement Detector (133 eV FwHm MnK). EDS spectra were acquired for 120 seconds (live time) with an accelerating voltage of $20 \mathrm{kV}$ and beam current of $0.84-0.86 \mathrm{nA}$. Spectra were processed with the LINK-ISIS SEMQUANT software package with full ZAF corrections using wellcharacterized natural and synthetic standards.

\section{Phase Relationships}

Figure 1 illustrates liquidus and subliquidus phase relation ships for this bulk composition as deduced from examination of the products of the experiments. All crystals in these products are newly-formed and not relicts of the starting material. The sub-liquidus region is divided into regions of phase assemblages representing the appearance of new phases as the melt cools. All of these lines, which should be regarded as approximate in their position, do not represent phase boundaries as they violate Schreinemakers rules; e.g. a four phase field is expected below the three pha se olivine-garnet-liquid field rather than the observed five phase region.

The experiments indicate th at the liquidus for this bulk composition rises steeply from about $1300^{\circ} \mathrm{C}$ at $5 \mathrm{GPa}$ to about $1400^{\circ} \mathrm{C}$ at $10 \mathrm{GPa}$. This slope is similar to that determined by Edgar \& Charbonneau (1993) for the Wesselt on aphan itic kimber lite but lies at much lower temperatures (approx. $1560^{\circ} \mathrm{C}$ at $5 \mathrm{GPa} ; 1625^{\circ} \mathrm{C}$ at 10 GPa). The liquidus phase is olivine over the pressure range investigated $(5-7 \mathrm{GPa})$ is forsteritic olivine. This is followed with decreasing temperature by the olivine plus garn et as the in itial sub-liquidus solid phase assemblage. It can be expected that the olivine-only region will probably "wedge-out" with increasing pressureas olivine is replaced by olivine plus garnet as the liquidus phases. Garnets in the near-liquidus region are Ti-Ca-rich varieties (see below) belonging to the pyrope-grossularalmandine solid solution series (Dawson and Stephens' group 6) and are thus compositionally-distinct from pyrope garnets of the megacryst/macrocryst suite (Dawson and Stephens' groups $1 \& 2$ ). Notably absent as liquidus or near-liquidus phases are pyrope, orthopyroxene, and clinopyroxene.

Regardless of the differences in bulk composition the phase relationships established in these experiments are identical to those observed by Edgar \& Charbonneau (1993), who also observed a wide three phase field ofgarnet + olivine + liquid as a near-liquidus phase assemblage. They differ in that the appea rance of this assemblage occurred at much high temperatures; approx. $1475^{\circ} \mathrm{C}$ versus $1280^{\circ} \mathrm{C}$ (this work) at $6 \mathrm{GPa}$.

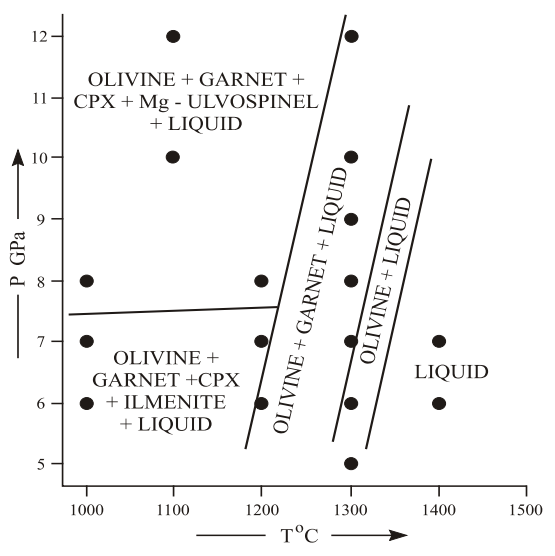

Figure 1. Phase relationships of Ondermatjie kimberlite

The absence of orthopyroxene, clinopyroxene and pyrope as near-liquidus phases in the experiments implies that, under the conditions used, liquid is not in equilibrium with a garnet lherzolite assemblage, and there this rock cannot be the source of kimberlite magmas.

In contrast to that of Edgar \& Charbonneau (1993), this study extended the investigation to near- 
solidus conditions $\left(900-1000^{\circ} \mathrm{C}\right.$ at $\left.6-8 \mathrm{GPa}\right)$. Figure 1 shows that supra-solidus assemblages consist of olivine+garnet+clinopyroxene+ilmenite $(+/-$ perovskite)+liquid at 5-7 GPa or olivine+garnet+clinopyr oxene+Mg-ul vospinel (+/perovskite)+liquid at 8-12 GPa. These data suggest that primary clinopyroxene might have been found in the experiments of Edgar \& Charbonneau (1993) at temperat ures below $1300^{\circ} \mathrm{C}$; the lowest they investigated. These data also indicate that kimberlite magmas are unlikely to be derived from simple garnet lherzolite sources.

\section{Pyroxene-oxide Intergrowths.}

One interesting, and unexpected, result of the experiments is the formation of orientated intergrowths between iron titanium oxides and silicates. The textures formed are identical to the lam ellar in tergrowth s between magnesian ilmenite and clinopyroxene found in some megacrysts. The experimentally-formed oxide-silicate intergrowths occur between magnesium ilmenite and clinopyroxene at pressures less than $7.5 \mathrm{GPa}$, and between magnesian ulvospinel (qandilite) - ulvospinel solid solutions above this pressure. In addition intergrowths between spinel and olivine are also formed at $12 \mathrm{GPa}$. These intergrowths are considered not to result from ex solution of the oxide from a phase enrich ed in $\mathrm{Ti}, \mathrm{Mg}$ and $\mathrm{Fe}$. They undoubtedly represent a directionally-solidified intergrowth involving rapid crystallization at a (pseudo?)cotectic.

Ilmenites and clinopyroxenes in the intergrowths are similar in composition to those of the natural material (Table 1; Figs. 2 \& 3). Spinel solid solutions in the intergrowths are dominated by the ulvospinel component (Table 2), and associated clinopyroxenes are Ca-rich relative to pyroxene associated with ilmenite (Fig. 2).

Garnets formed in the experiments exhibit a range in composition with respect to their $\mathrm{Ti}, \mathrm{Al}, \mathrm{Mg}$, and $\mathrm{Fe}$ contents (Table 1). Many have Fe-enrich ed quench rims. There is no apparent relation between $\mathrm{Ti}$ content or $\mathrm{Mg} / \mathrm{Mg}+\mathrm{Fe}$ ratio and condition s of formation. They are unusual in that their overall composition is $(\mathrm{Ca}, \mathrm{Mg})_{3}(\mathrm{Al}, \mathrm{Fe}, \mathrm{Ti}, \mathrm{Cr})_{2}\left(\mathrm{Si}_{3} \mathrm{O}_{12}\right)$ and are thus members of the grossular-pyrope-almandine solid solution series, and similar to eclogitic garnets rather than the pyrope garnets found in garnet lherzolites. Garnets of similar composition were formed in the experiments of Edgar \& Charbonneau (1993).

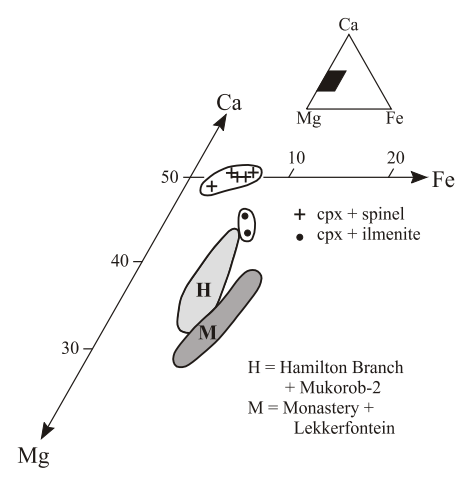

Figure 2. Compositions of clinopyroxenes in intergrowths.

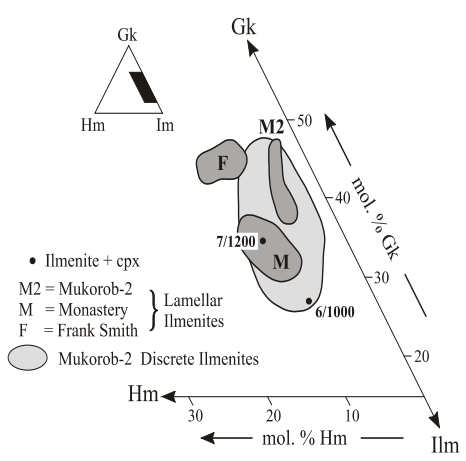

Figure 3. Compositions of ilmenite in intergrowths

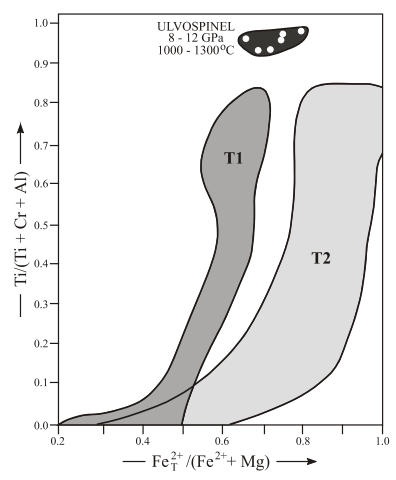

Figure 4 Compositions of spinel in intergrowths. 
Quench Liquids are carbonates which exhibit a very wide range in composition. Those occurring in the mesostasis to primary and quen ch silicate assemblageare primarily dolomitic-to-magn esitic e.g. $40.7 \mathrm{wt} \% \mathrm{MgO}$, $4.5 \%$ wt. $5 \mathrm{FeO} ; 2.7$ wt. $\% \mathrm{CaO}$ at $12 \mathrm{GPa} / 1300^{\circ} \mathrm{C} ; 35.1$ wt. $\% \mathrm{MgO}, 2.2$ wt. $\% \mathrm{CaO}, 4.6$ wt. $\% \mathrm{MgO}$ at $8 \mathrm{GPa} / 1000^{\circ} \mathrm{C} ; 9.7$ wt.\% $\mathrm{MgO}, 38.5$ wt. $\% \mathrm{CaO}, 1.76$ wt. $\% \mathrm{FeO}$. Segregated quenched liquids are mixtures of cryptocrystalline silicate and dolomitic carbonate containing several wt. $\% \quad \mathrm{~K}_{2} \mathrm{O} \quad(7.3$ wt.\% at 12 $\mathrm{GPa} / 1300^{\circ} \mathrm{C} ; 8.3$ wt. $\%$ at $\left.7 \mathrm{GPa} / 1400^{\circ} \mathrm{C}\right)$.

Conclusions The experimental data are interpreted to indicate that thecrystallization sequen ce from liquidus to solidus of this bulk composition is: olivine; olivine + Tigarnet; olivine + Ti-garnet + clinopyroxene $+\mathrm{Fe}-\mathrm{Ti}$ oxide. The subsolidus assemblage will probably consist of olivine-Ti-garnet - clin opyroxene - Fe-Ti-oxide $\mathrm{CaTiO}_{3}$-magnesite-rich carbon ate. The con centration of $\mathrm{K}$ in segregated liquids suggests that phlogopite might also occur. This assemblage is considered to exist as veins in a metasomatised asthenospheric mantle substrate.

\section{REFERENCES:}

Edgar,A.D., Charbonneau, H.E. 1993. Melting exper iment s on a $\mathrm{SiO}_{2}$-poor, $\mathrm{CaO}$-rich aphanitic kimberlite from 5-10 GPa and their bearing on sources of kimberlite magmas. American Mineralogist 78, 132-142.

Foley, S.F. 1992. Vein plus wall rock melting mechanisms in the lithosphere and the origin of potassic magmas. Lithos 28, 435-453.

Mitchell, R.H. Kimberlites, 1995. Orangeites and Related Rocks. Plenum Press, New York.

Walter, M.J., Thibault,Y., Wei, K., Luth, R.W. 1995.

Characterizing experimental pressure and temperature conditions in multianvil apparatus. Canadian Journal of Physics, 73, 273-286. 
Table 1. Composition (wt.\%) of clinopyroxene in intergrowths and garnets

\begin{tabular}{|c|c|c|c|c|c|c|c|}
\hline $\mathrm{P} / \mathrm{T}$ & $6 / 1000$ & $7 / 1200$ & $8 / 1000$ & $8 / 1400$ & $10 / 1100$ & $6 / 1300$ & $8 / 1400$ \\
\hline $\mathrm{SiO}_{2}$ & 53.36 & 52.88 & 54.95 & 54.32 & 54.49 & 37.10 & 37.65 \\
\hline $\mathrm{TiO}_{2}$ & 0.43 & 0.71 & 0.46 & 0.48 & 0.23 & 8.46 & 5.53 \\
\hline $\mathrm{Al}_{2} \mathrm{O}_{3}$ & 1.53 & 1.17 & 0.53 & 0.63 & 0.18 & 11.54 & 10.70 \\
\hline $\mathrm{Cr}_{2} \mathrm{O}_{3}$ & 0.11 & 0.14 & n.d. & n.d. & 0 & 0.10 & 0.14 \\
\hline $\mathrm{Fe}_{2} \mathrm{O}_{3}$ & 0 & 1.74 & 0 & 0 & 0.10 & - & - \\
\hline $\mathrm{FeO}$ & 5.53 & 3.75 & 3.37 & 2.91 & 1.98 & 10.44 & 12.98 \\
\hline $\mathrm{MnO}$ & n.d. & 0.25 & 0.13 & 0.10 & n.d. & 0.39 & 0.20 \\
\hline $\mathrm{MgO}$ & 15.31 & 16.70 & 18.63 & 18.40 & 17.68 & 8.73 & 12.61 \\
\hline $\mathrm{CaO}$ & 23.02 & 22.70 & 23.12 & 22.85 & 24.48 & 22.60 & 19.35 \\
\hline $\mathrm{Na}_{2} \mathrm{O}$ & n.d. & 0.22 & n.d. & n.d. & 0.11 & - & - \\
\hline Total & 99.29 & 100.27 & 101.21 & 99.69 & 99.25 & 99.36 & 99.16 \\
\hline \multicolumn{8}{|c|}{ Mol. \% End Member Components } \\
\hline $\mathrm{CaTiAl}_{2} \mathrm{O}_{6}$ & 1.23 & 1.95 & 1.12 & 1.18 & 0.39 & & \\
\hline $\mathrm{CaAl}(\mathrm{SiAl}) \mathrm{O}_{6}$ & 0.37 & 0 & 0 & 0 & 0 & & \\
\hline Ac & 0 & 1.56 & 0 & 0 & 0.78 & & \\
\hline Wo & 46.15 & 43.54 & 43.53 & 44.19 & 47.81 & & \\
\hline Fs & 8.80 & 7.36 & 5.06 & 4.45 & 2.78 & & \\
\hline En & 43.45 & 45.58 & 49.89 & 50.18 & 48.24 & & \\
\hline Coexisting phase & ILM & ILM & SP & SP & SP & & \\
\hline
\end{tabular}

Table 2. Compositions (wt.\%) of ilmenite and spinels in intergrowths.

\begin{tabular}{|c|c|c|c|c|c|c|c|}
\hline $\mathrm{P} / \mathrm{T}$ & $6 / 1000$ & $7 / 1200$ & & $8 / 1000$ & $8 / 1300$ & $10 / 1100$ & $12 / 1100$ \\
\hline $\mathrm{TiO}_{2}$ & 49.33 & 50.76 & & 35.55 & 32.92 & 33.31 & 32.95 \\
\hline $\mathrm{Al}_{2} \mathrm{O}_{3}$ & 0.54 & 0.64 & & 0.95 & 1.48 & 0.44 & 0.52 \\
\hline $\mathrm{Cr}_{2} \mathrm{O}_{3}$ & 0.16 & 0.20 & & 0.16 & 0.25 & 0.23 & 0.05 \\
\hline $\mathrm{Fe}_{2} \mathrm{O}_{3}$ & 9.56 & 12.16 & & 0.10 & 7.99 & 5.70 & 8.11 \\
\hline $\mathrm{FeO}$ & 30.92 & 27.77 & & 50.97 & 46.28 & 50.60 & 47.85 \\
\hline $\mathrm{MnO}$ & 0.39 & 0.28 & & 0.10 & 0.22 & 0.22 & 0.56 \\
\hline \multirow[t]{2}{*}{$\mathrm{MgO}$} & 7.32 & 9.87 & & 7.66 & 9.80 & 6.77 & 8.35 \\
\hline & 98.22 & 101.68 & & 95.49 & 98.94 & 97.27 & 98.39 \\
\hline \multicolumn{8}{|c|}{ Mol.\% End member components } \\
\hline $\mathrm{Al}_{2} \mathrm{O}_{3}$ & 0.77 & 0.87 & $\mathrm{MgAl}_{2} \mathrm{O}_{4}$ & 1.37 & 2.05 & 0.63 & 0.73 \\
\hline $\mathrm{Cr}_{2} \mathrm{O}_{3}$ & 0.15 & 0.18 & $\mathrm{Mg}_{2} \mathrm{TiO}_{4}$ & 19.96 & 24.17 & 17.92 & 21.64 \\
\hline $\mathrm{Hm}$ & 8.76 & 10.59 & $\mathrm{MgCr}_{2} \mathrm{O}_{4}$ & 0 & 0 & 0 & 0 \\
\hline Py & 0.80 & 0.55 & $\mathrm{MnCr}_{2} \mathrm{O}_{4}$ & 0 & 0 & 0 & 0 \\
\hline Gk & 26.57 & 34.06 & $\mathrm{Mn}_{2} \mathrm{TiO}_{4}$ & 0.16 & 0.33 & 0.34 & 0.85 \\
\hline \multirow[t]{3}{*}{$\mathrm{Ilm}$} & 62.94 & 53.74 & $\mathrm{Fe}_{2} \mathrm{TiO}_{4}$ & 78.22 & 62.64 & 73.07 & 65.86 \\
\hline & & & $\mathrm{FeCr}_{2} \mathrm{O}_{4}$ & 0.16 & 0.23 & 0.22 & 0.05 \\
\hline & & & $\mathrm{Fe}_{3} \mathrm{O}_{4}$ & 0.13 & 10.59 & 7.82 & 10.88 \\
\hline
\end{tabular}

